\title{
Diffuse Neurofibroma
}

National Cancer Institute

\section{Source}

National Cancer Institute. Diffuse Neurofibroma. NCI Thesaurus. Code C8426.

A rare neurofibroma with an infiltrative growth pattern. It involves the skin and subcutaneous tissue and grows in a plaque-like fashion. Malignant transformation is rare. 